\title{
Increased renal and forearm vasoconstriction in response to exercise after heart transplantation
}

Guy A Haywood, Peter J Counihan, James F Sneddon, Stephen H Jennison, Yaver Bashir, William J McKenna

\begin{abstract}
Objective-To test the hypothesis that the loss of the inhibitory effect of the cardiac ventricular afferent fibres on the vasomotor centre would result in increased vasoconstrictor drive to the forearm and renal vascular beds during supine exercise in heart transplant recipients.

Design-Comparison of regional haemodynamic response to exercise in heart transplant recipients and two age matched control groups.

Setting-Regional heart transplant unit. Patients and methods-Orthotopic heart transplant recipients $(n=10)$, patients with NYHA class II heart failure $(n=10)$, and normal controls $(n=10)$ underwent short duration maximal supine bicycle exercise.
\end{abstract}

Main outcome measures-Simultaneous measurements were made of heart rate, systemic blood pressure, oxygen consumption $\left(\mathrm{Vo}_{2}\right)$, forearm blood flow, and renal blood flow. Forearm blood flow was measured by forearm plethysmography and renal blood flow by continuous renal vein thermodilution.

Results-The peak forearm vascular resistance was significantly greater in the transplant group than in the controls (mean (SEM) 75 (18) $v 40$ (7) resistance units, $p<0.05)$. The percentage fall in renal blood flow at peak exercise was significantly greater in heart transplant recipients than in the controls $(44 \%(4 \%)$ $v 32 \%(4 \%), p<0.05)$ as was the percentage increase in renal vascular resistance (transplants: $116 \%(19 \%) v$ controls: $78 \%$ $(17 \%), p<0.05)$. Regional haemodynamics during exercise in the heart failure group were not significantly different from those in the controls.

Conclusions-These findings suggest that surgical division of the cardiac ventricular afferent fibres results in increased vasoconstrictor drive to the kidneys and non-exercising muscle during exercise. This mechanism may contribute to persistent exercise limitation and renal impairment after heart transplantation.

(Br Heart f 1993;70:247-251)

During exercise in humans, blood flow is diverted away from the kidneys and non-exercising muscle and towards exercising muscle groups. ${ }^{12}$ This mechanism is controlled by the complex interaction of local metabolic and neurohumoral factors, and the sympathetic efferent output arising from the vasomotor centre directed to the individual vascular beds. ${ }^{3}$ In animals, non-myelinated vagal afferent $C$ fibres arising from ventricular mechanoreceptors in the heart have been shown to exert an inhibitory influence on the vasomotor centre, modulating the level of central efferent sympathetic outflow. ${ }^{4}$

Animal studies suggest that the region of the circulation most influenced by cardiac vagal afferent input to the vasomotor centre is the renal vascular bed, ${ }^{56}$ but whether this is so in humans is not known.

There is also no information, except during prolonged lower body negative pressure, ${ }^{7}$ on whether changes in vascular resistance in muscle reflect changes in the vascular tone of internal organs, such as the kidneys. Most studies of cardiovascular reflexes in humans have concentrated on muscle with either forearm plethysmography, ${ }^{8}$ or more recently, microneurographic recordings of peroneal sympathetic nerve traffic ${ }^{9}$; whether results from these studies can be extrapolated to other regional circulations is unknown. This study tested the hypothesis that removal of cardiac ventricular afferent nerves resulting from cardiac transplantation would remove the inhibitory influence of vagal afferent $C$ fibres on the vasomotor centre. This could result in enhanced vasoconstrictor responses in the forearm and renal vascular beds during dynamic leg exercise and the vasoconstriction in the renal vascular bed would be similar to that found in the forearm.

\section{Patients and methods}

SUBJECTS

The subjects who participated in the study were: 10 symptom free patients, all men, 2.5-9 months after orthotopic heart transplantation, 10 patients with grade II New York Heart Association heart failure (seven cardiomyopathies, two ischaemic heart disease, and one valvar heart disease-aortic regurgitation), five men and five women, and 10 controls composed of patients with normal electrocardiograms and structurally normal hearts who were undergoing electrophysiological evaluation for detection of concealed accessory pathways or who had been referred with intermittent non-exertional chest pain and had been shown to have normal exercise tests, normal coronary arteriography, and normal coronary flow reserve (eight men and 
two women). All subjects gave fully informed written consent in a format approved by the hospital ethics committee. Patients with a history of systemic hypertension, intrinsic renal disease, or a serum creatinine greater than $160 \mu \mathrm{mol} / 1$ were excluded. In the heart transplant patients the study was performed immediately before routine endomyocardial biopsy. All biopsies were free of histological evidence of acute rejection.

\section{Medications at the time of the study}

Heart transplant patients were all maintained on cyclosporin and azathioprine and two were also receiving $10 \mathrm{mg}$ of prednisolone daily. The heart failure group were all receiving small doses of a loop diuretic, also, three were receiving an angiotensin converting enzyme inhibitor. Control subjects were on no drug treatment. Subjects received no medication for 24 hours before the study.

\section{METHODS}

Measurements were made after 20 minutes of supine rest and repeated in the last minute of exercise. Heart rate was measured from an instantaneous electrocardiographic monitor. Oxygen consumption $\left(\mathrm{Vo}_{2}\right)$ and respiratory quotient (RQ) were measured after 20 minutes rest in the supine position and continuously throughout exercise by respiratory gas analysis with a metabolic measurement cart (Sensor Medics Horizon MMC). ${ }^{10}$ Forearm blood flow was measured by forearm venous occlusion plethysmography with a mercury in silastic temperature compensated strain gauge. ${ }^{11} 12$ Left renal blood flow was measured by continuous renal vein thermodilution. ${ }^{13}$ Heart rate (beats $/ \mathrm{min}), \mathrm{VO}_{2}(\mathrm{ml} / \mathrm{kg} / \mathrm{min}), \mathrm{RQ}$, forearm blood flow ( $\left.\mathrm{ml} 100 \mathrm{ml}^{-1} \cdot \mathrm{min}^{-1}\right)$, and left renal blood flow $(\mathrm{ml} / \mathrm{min}$ ) were measured simultaneously after 20 minutes of rest in the supine position with the subjects' feet strapped to the pedals of a supine exercise bicycle. A short duration maximal exercise protocol was used. ${ }^{14}$ Work load was adjusted to result in a progressive rise in heart rate over the first seven minutes of exercise, after which the workload was set to the maximum that subjects could tolerate and they were instructed to pedal "flat out" to exhaustion. Resistance units for the forearm and kidney were calculated by dividing the mean arterial blood pressure by the forearm blood flow in $\mathrm{ml} / 100 \mathrm{ml} / \mathrm{min}$ or the left renal blood flow in $\mathrm{ml} / \mathrm{min}$. Renal oxygen delivery and consumption were calculated from the renal blood flow, haemoglobin, and the arterial and renal venous oxygen saturations from standard formulae.

\section{STATISTICAL ANALYSIS}

Results are presented as mean (SEM). The differences between the controls and the heart failure and transplant groups were analysed with the Mann-Whitney U test. The Spearman correlation coefficient was calculated for the percentage changes in forearm and renal vascular resistance in individual subjects.

\section{Results}

There were no significant differences in the ages of the three groups (controls 45 (5) years, transplant recipients 48 (2) years, heart failure patients 42 (4) years). The resting heart rate was 89 (3) beats/min in the transplant group, significantly greater than that in controls (74 (3), p < 0.01), but similar to that in the heart failure group (83 (4) NS). All patients achieved their maximal exercise within 10 to 12 minutes from the start of exercise. At maximal exercise controls achieved a greater peak heart rate (149 (6) beats/min) than either the heart failure patients $(118$ (4) $\mathrm{p}<0.01)$ or the transplant patients $(116$ (3) $\mathrm{p}<0.01)$. There were no significant differences in either resting or peak mean arterial blood pressures between the controls and the other two groups (resting: controls 99 (5), heart failure 106 (8), transplants 111 (5) $\mathrm{mm} \mathrm{Hg}$, peak: controls 123 (6), heart failure 103 (5), transplants 126 (7). Table 1 shows exercise data for the three groups. The $\mathrm{Vo}_{2} \max$ was $24(2 \cdot 4) \mathrm{ml} / \mathrm{kg} / \mathrm{min}$ in controls, greater than in the heart failure patients $(16(2.0) \mathrm{p}<0.01)$ and heart transplant recipients $(16(1.0), \mathrm{p}<0.01)$. The respiratory quotient achieved was $1 \cdot 1(0.02)$ in the controls and $1.1(0.02)$ in the transplant recipients, indicating that they had exercised to beyond the anaerobic threshold. Some of the patients with heart failure were symptom limited before reaching a respiratory quotient greater than $1.0(0.9(0.05))$. The $\mathrm{VO}_{2}$ data was unavailable from one patient in the transplant group because his beard prevented an airtight seal between the mask and his face, and from two patients in the heart failure group who were unable to tolerate the face mask. Table 2 shows the changes in forearm blood flow in response to exercise and table 3 shows the renal blood flow.

\section{FOREARM BLOOD FLOW}

The percentage fall in forearm blood flow at peak exercise in heart transplant recipients $(39 \%(10 \%))$ was not significantly greater than in controls $(32 \%(6 \%))$ or in heart failure patients $(22 \%(7 \%))$. The peak forearm

Table 1 Mean (SEM) systemic variables during exercise in controls, heart transplant recipients (TXpts), and patients with heart failure (CCF Pts)

\begin{tabular}{|c|c|c|c|c|c|c|c|}
\hline & Age (yr) & $\begin{array}{l}\text { Resting } \\
\text { heart rate } \\
\text { (beats/min) }\end{array}$ & $\begin{array}{l}\text { Peak heart } \\
\text { rate } \\
\text { (beats/min) }\end{array}$ & $\begin{array}{l}\text { Resting } \\
M A B P \\
(m m \mathrm{Hg})\end{array}$ & $\begin{array}{l}\text { Peak } \\
M A B P \\
(m m \mathrm{Hg})\end{array}$ & $\begin{array}{l}\text { Peak } \\
\text { Vo } \\
\text { (ml/kg/min) }\end{array}$ & $R Q$ \\
\hline $\begin{array}{l}\text { Controls }(n=10) \\
\text { TX Pts }(n=10) \\
\text { CCF Pts }(n=10)\end{array}$ & $\begin{array}{l}45(5) \\
48(2) \\
42(4)\end{array}$ & $\begin{array}{l}74(3) \\
89(3)^{\star} \\
83(4)\end{array}$ & $\begin{array}{l}149(6) \\
116(3)^{\star} \\
118(4)^{\star}\end{array}$ & $\begin{array}{r}99(5) \\
111(5) \\
106(8)\end{array}$ & $\begin{array}{l}123(6) \\
126(7) \\
103(5)\end{array}$ & $\begin{array}{l}24(2 \cdot 4) \\
16(1 \cdot 0)^{\star} \\
16(2 \cdot 0)^{\star}\end{array}$ & $\begin{array}{l}1.1(0.02) \\
1.1(0.02) \\
0.9(0.05)\end{array}$ \\
\hline
\end{tabular}

${ }^{\star} \mathrm{p}<0.01 v$ controls. MABP, mean arterial blood pressure. 
Table 2 Changes in mean (SEM) forearm blood flow (FBF) and forearm vascular resistance (FVR)

\begin{tabular}{|c|c|c|c|c|c|c|}
\hline & $\begin{array}{l}\text { Resting } \\
F B F \\
(\mathrm{ml} / 100 \mathrm{ml} / \mathrm{min})\end{array}$ & $\begin{array}{l}\text { Peak } \\
F B F \\
(\mathrm{ml} / 100 \mathrm{ml} / \mathrm{min})\end{array}$ & $\begin{array}{l}\text { Fall } \\
\text { FBF } \\
(\%)\end{array}$ & $\begin{array}{l}\text { Resting } \\
\text { FVR } \\
\text { (Res units) }\end{array}$ & $\begin{array}{l}\text { Peak } \\
\text { FVR } \\
\text { (Res units) }\end{array}$ & $\begin{array}{l}\text { Increase } \\
F V R \\
(\%)\end{array}$ \\
\hline $\begin{array}{l}\text { Controls } \\
\text { Tx Pts } \\
\text { CCF Pts }\end{array}$ & $\begin{array}{l}5.3(0.5) \\
4.3(0.6) \\
3 \cdot 4(0.4)^{\star \star}\end{array}$ & $\begin{array}{l}3.5(0.5) \\
2 \cdot 2(0.4) \\
2 \cdot 6(0.4)\end{array}$ & $\begin{array}{l}32(6) \\
39(10) \\
22(7)\end{array}$ & $\begin{array}{l}21(2) \\
32(6) \\
40(5)\end{array}$ & $\begin{array}{l}40(7) \\
75(18)^{\star \star} \\
48(7)\end{array}$ & $\begin{array}{l}97(36) \\
183(54) \\
34(13)^{\star}\end{array}$ \\
\hline
\end{tabular}

${ }^{\star} \mathrm{p}<0.05 v$ controls (one tailed Mann Whitney $U$ test); ${ }^{\star \star} \mathrm{p}<0.05 v$ controls (two tailed Mann Whitney U test); Res units, resistance units; other abbreviations as for table 1 .

Table 3 Changes in mean (SEM) renal blood flow (RBF) and renal vascular resistance $(R V R)$

\begin{tabular}{|c|c|c|c|c|c|c|}
\hline & $\begin{array}{l}\text { Resting } \\
\text { left RBF } \\
(\mathrm{ml} / \mathrm{min})\end{array}$ & $\begin{array}{l}\text { Peak } \\
\text { lefi RBF } \\
\text { (ml/min) }\end{array}$ & $\begin{array}{l}\text { Fall } R B F \\
(\%)\end{array}$ & $\begin{array}{l}\text { Resting } \\
\text { RVR } \\
\text { (Res units) }\end{array}$ & $\begin{array}{l}\text { Peak } \\
\text { RVR } \\
\text { (Res units) }\end{array}$ & $\begin{array}{l}\text { Increase } \\
R V R(\%)\end{array}$ \\
\hline $\begin{array}{l}\text { Controls } \\
\text { Tx Pts } \\
\text { CCF Pts }\end{array}$ & $\begin{array}{l}456(44) \\
428(78) \\
483(64)\end{array}$ & $\begin{array}{l}316(39) \\
245(56) \\
320(58)\end{array}$ & $\begin{array}{l}32(4) \\
45(5)^{\star \star} \\
38(5)\end{array}$ & $\begin{array}{l}0.24(0.02) \\
0.35(0.07) \\
0.26(0.03)\end{array}$ & $\begin{array}{l}0.43(0.06) \\
0.72(0.13)^{\star} \\
0.49(0.13)\end{array}$ & $\begin{array}{r}78(17) \\
116(19)^{\star} \\
65(24)\end{array}$ \\
\hline
\end{tabular}

${ }^{\star} \mathrm{p}<0.05 v$ controls (one tailed Mann Whitney U test); ${ }^{\star \star} \mathrm{p}<0.05 v$ controls (two tailed Mann Whitney $U$ test); abbreviations as for tables 1 and 2.

vascular resistance was, however, significantly greater in the transplant group than in controls $(75$ (18) $v 40$ (7) resistance units, $\mathrm{p}<$ $0.05)$. The peak forearm vascular resistance in the heart failure group (48 (7) resistance units) showed no significant difference from the controls. Compared with controls, patients with heart failure had a lower percentage increase in forearm vascular resistance (34 (13) $v 97$ (36) resistance units).

\section{RENAL BLOOD FLOW}

The percentage fall in renal blood flow at peak exercise was significantly greater in heart transplant recipients than in controls (44\% (4\%) $v 32 \%(4 \%), \mathrm{p}<0.05)$ and the percentage increase in renal vascular resistance was significantly greater (transplants: $116 \%$ (19\%) $v$ controls $78 \%(17 \%), \mathrm{p}<0.05)$. The heart failure group was not significantly different from controls in either percentage fall in renal blood flow $(38 \%(5 \%))$ or percentage increase in renal vascular resistance $(65 \%(24 \%))$.

\section{RENAL OXYGEN CONSUMPTION}

Table 4 shows the changes in renal oxygen consumption and renal oxygen extraction ratio. The Spearman rank correlation between percentage changes in forearm and renal vascular resistance in individual subjects was $0.56(\mathrm{p}<0.002)$ (figure).

\section{Discussion}

The effects of sympathetic drive on the vascular tone of different regions of the circulation

Table 4 Mean (SEM) values for left renal oxygen consumption $\left(\mathrm{RVO}_{2}\right)$ and renal oxygen extraction ratio $\left(\mathrm{O}_{2}\right.$ Extr Ratio)

\begin{tabular}{|c|c|c|c|c|}
\hline & & Before exercise & After exercise & P Value \\
\hline $\begin{array}{l}\text { Controls } \\
\text { Controls } \\
\text { TxPts } \\
\text { TxPts } \\
\text { CCF Pts } \\
\text { CCF Pts }\end{array}$ & $\begin{array}{l}\mathrm{RVO}_{2} \mathrm{ml} / \mathrm{min} \\
\mathrm{O}_{2} \text { Extr Ratio \% } \\
\mathrm{RVO}_{2} \mathrm{ml} / \mathrm{min} \\
\mathrm{O}_{2} \text { Extr Ratio \% } \\
\mathrm{RVO}_{2} \mathrm{ml} / \mathrm{min} \\
\mathrm{O}_{2} \text { Extr Ratio \% }\end{array}$ & $\begin{array}{l}6 \cdot 2(0 \cdot 6) \\
8(1) \\
7 \cdot 4(1 \cdot 8) \\
11(1) \\
11 \cdot 2(3 \cdot 9) \\
19(4)\end{array}$ & $\begin{array}{c}6 \cdot 2(1 \cdot 0) \\
11(2) \\
9 \cdot 1(3 \cdot 2) \\
26(6) \\
9 \cdot 9(3 \cdot 6) \\
28(7)\end{array}$ & $\begin{array}{l}\text { NS } \\
<0.01 \\
\text { NS } \\
<0.01 \\
\text { NS } \\
<0.01\end{array}$ \\
\hline
\end{tabular}

Abbreviations as for table 1 .

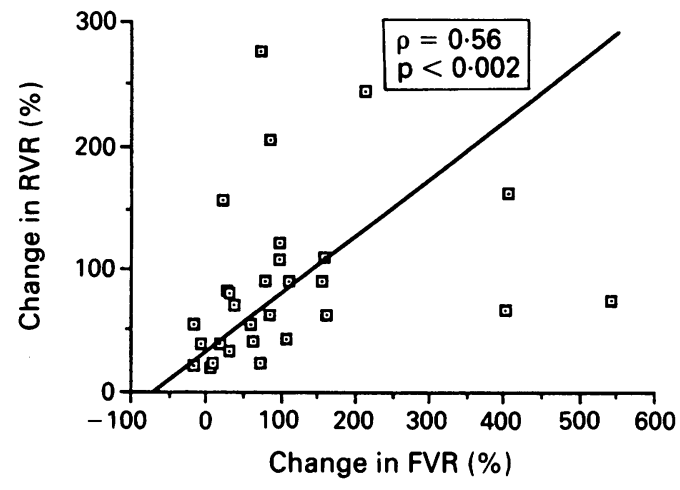

Correlation between percentage changes in forearm (FVR) and renal (RVR) vascular resistances from rest to peak exercise in individual subjects. ( $\rho=$ the Spearman rank correlation coefficient).

during exercise have been investigated in animals and humans. ${ }^{121516}$

THE FOREARM VASCULAR BED

The normal response to supine leg exercise in the resting forearm is vasoconstriction. ${ }^{817}$ The vascular resistance of the forearm is known to be modulated by input to the vasomotor centre from cardiac afferent fibres. ${ }^{18}$ The normal inhibitory input of these fibres to the vasomotor centre seems to be lost after cardiac transplantation; lower body negative pressure $(-10 \mathrm{~mm} \mathrm{Hg})$, which turns nerve traffic off in these fibres, results in a significantly smaller increase in forearm vascular resistance in heart transplant recipients than in controls or renal transplant patients. ${ }^{19}$ It is known that the response of the cardiovascular system to dynamic leg exercise remains abnormal after cardiac transplantation. ${ }^{20-23}$ However, the influence of removal of cardiac afferent nerves on forearm vascular resistance during maximal exercise has not been investigated in heart transplant recipients.

The results from this study show increased vasoconstriction in the forearm during maximal, supine, dynamic, leg exercise.

\section{THE RENAL VASCULAR BED}

The effect of exercise on renal blood flow varies in different species. ${ }^{23}{ }^{24}$ In the dog, it is noticeably influenced by left ventricular function, ${ }^{25}$ whereas in humans changes in renal blood flow seem to be dependent on the exercise intensity, ${ }^{26}$ duration, ${ }^{27}$ posture, ${ }^{28,29}$ and ambient temperature. ${ }^{30}$ The fall in renal blood flow in all three groups in the study reported here was smaller than that reported during strenuous supine exercise by other investigators. ${ }^{27}$ The conclusions drawn from previous studies in humans, however, must be interpreted in the light of methodological limitations. All previous investigators have relied on clearance techniques for the measurement of renal blood flow, principally with sodium $p$-aminohippurate $(\mathrm{PAH})$. Clearance techniques measure effective renal plasma flow. To convert this value to total renal blood flow, the packed cell volume and arteriovenous extraction ratio for PAH must be known. Bucht and colleagues measured 
the PAH extraction ratio at rest and during moderate exercise in three subjects and found no significant change, ${ }^{29}$ but a fall in the PAH extraction fraction at maximal exercise, if not accounted for in clearance calculations, would result in underestimation of renal blood flow. A further limitation of applying clearance techniques to the study of exercise is that they are unsuited to the measurement of rapidly changing haemodynamic states. ${ }^{31}$ In practice a steady state must be maintained for at least 15 minutes if the values for renal blood flow are to approach an acceptable level of accuracy. Most investigators have therefore been forced to study long duration sub-maximal exercise. Because the continuous renal vein thermodilution technique allows direct measurement of renal blood flow to be achieved over about 30 seconds, these methodological problems did not arise. By contrast the theoretical weaknesses of the continuous renal vein thermodilution technique are that measurements are limited to the blood flow in the left kidney rather than in both kidneys. As there is no reason to believe that neural regulation of renal blood flow affects the two kidneys differentially this is unlikely to be of importance. The technique has been extensively validated. ${ }^{13}$

In conclusion, the methodological differences and the shorter duration of the exercise protocol used may explain the smaller decreases in renal blood flow found in this study compared with the findings of previous investigators. The results indicate that the increased vasoconstriction in response to exercise found in the forearm is also present in the renal vascular bed in patients who have undergone heart transplantation.

\section{RENAL OXYGEN CONSUMPTION IN RESPONSE TO EXERCISE}

Patients with heart failure increase the percentage of oxygen extracted from the blood stream by the kidneys during exercise. ${ }^{32}$ This is the first study to report oxygen extraction by the human kidney at maximal exercise and it would seem that the phenomenon found in patients with heart failure at lower levels of exercise, is also present in controls and heart transplant recipients at peak exercise.

\section{IS THE MECHANISM VENTRICULAR} DEAFFERENTATION?

In interpreting the results from this study, care must be taken in assigning causal explanations to the increased reflex vasoconstriction found in the forearm and kidney during leg exercise, as there are many differences between controls and heart transplant recipients other than cardiac denervation. The results seem, however, to parallel studies on the effects of cardiac denervation in some animal models. DiCarlo and Bishop found that blockade of the cardiac vagal afferent fibres by intrapericardial procainamide injection, enhanced the vasoconstrictor response in the renal vascular bed during dynamic exercise in rabbits. ${ }^{24}$ Other explanations for the differences found might be effects of the antirejec- tion treatment on the response of the efferent sympathetic nervous system to exercise, or a chronic effect of cardiothoracic surgery other than cardiac denervation. There is some evidence that cyclosporin increases sympathetic nerve traffic and calf vascular resistance in the resting state, ${ }^{33}$ however, this influence should have been present both at rest and at peak exercise and does not therefore explain the greater percentage increase in vasoconstriction in response to exercise. In the forearm vascular bed the altered forearm vascular reflexes in response to lower body negative pressure seen after cardiac transplantation are not present in renal transplant patients on similar treatment ${ }^{19}$; the differences noted are therefore unlikely to be due to immunosuppressive treatment.

It also seems unlikely that the differences in regional haemodynamic responses to exercise result from the limited functional capacity of the cardiovascular system in heart transplant recipients. The heart failure group reached a similar $\mathrm{Vo}_{2}$ to the transplant recipients; although there was a trend towards increased renal vascular resistance, there was no significant difference in the peak forearm vascular resistance or the percentage fall in renal blood flow from that shown by the normal controls. It is also possible that decreased afferent input from arterial baroreceptors to the vasomotor centre might have resulted in increased sympathetic drive during exercise in the transplant recipients. Artificial increase of blood pressure by a noradrenaline bolus during static exercise in cats is known to reduce efferent sympathetic drive to the kidneys. ${ }^{34}$ This was thought to be due to stimulation of the arterial baroreflex. Although the peak blood pressures were similar in the control and transplanted groups, the increase in blood pressure from rest to peak exercise in controls was not significantly greater than in transplant recipients (24 (7) $v 15$ (5) $\mathrm{mm} \mathrm{Hg}$, NS). The mean blood pressure change in controls was, however, significantly greater than in the patients with heart failure $(24$ (7) $v-3(7) \mathrm{mm} \mathrm{Hg}, \mathrm{p}<0.05$ ) and yet there was no significant increase in renal or forearm vasoconstriction in the heart failure group compared with controls. It therefore seems unlikely that the principle cause of the increased vasoconstrictor drive seen in the transplant recipients was a lower level of stimulation of the arterial baroreflex.

\section{UNIFORMITY OF REGIONAL VASCULAR \\ REFLEXES}

This is the first report in humans of simultaneous measurement of the effects of exercise on the regional circulations of both a limb muscle bed and an internal organ. The mean percentage changes in forearm and renal blood flows are similar in the controls and heart transplant patients (controls: fall in forearm blood flow $32 \%(6 \%)$, fall in renal blood flow $32 \%$ (4\%); and transplants: fall in forearm blood flow $39 \%(10 \%)$, fall in renal blood flow $44 \%$ ( $4 \%$ ); however, there is some disparity between the responses in the two 
regions in the heart failure group (fall in forearm blood flow $22 \%(7 \%)$, fall in renal blood flow $38 \%(5 \%)$. Whether this reflects a differential effect of activated neurohumoral mechanisms on the two regions is speculative. Despite this there is a moderate correlation $(\rho=0.56, \mathrm{p}<0.002)$ between the changes in forearm and renal vascular resistance when the values for individual subjects are plotted for all patients in the study. Overall, the results suggest that short term changes in vascular tone in the limb muscle beds in response to sympathetically mediated cardiovascular reflexes, are broadly similar to those in the kidneys.

\section{PATHOPHYSIOLOGICAL SIGNIFICANCE}

The functional capacity of the circulation remains limited after heart transplantation despite normal resting ventricular ejection fractions. ${ }^{20-2235}$ The limitation of maximal oxygen consumption is thought to reflect limitation of the increase in cardiac output in response to exercise. Whereas this failure to mount a normal increase in cardiac output may be primarily explained by a blunted heart rate response during exercise, it is also possible that abnormally raised systemic vascular resistance resulting from increased vasoconstriction in non-exercising regions is a contributing factor. Evidence exists for gradual sympathetic efferent reinnervation of the transplanted heart ${ }^{36}$; vagal afferent reinnervation of the transplanted heart has not been found. Changes in exercise haemodynamics arising from the division of vagal afferent fibres may therefore be permanent. Renal impairment is one of the largest problems in the management of patients after heart transplantation. The most important cause of renal dysfunction in these patients is almost certainly the renal toxicity of cyclosporin. Part of the mechanism of cyclosporin induced renal toxicity is thought to be renal vasoconstriction. ${ }^{37}$ It is possible that the removal of the main cardiovascular reflex acting to moderate sympathetic vasoconstrictor drive to the kidney, ${ }^{56}$ is a contributing factor in those patients who develop renal impairment after heart transplantation.

Guy A Haywood, James F Sneddon, and Yaver Bashir were supported by British Heart Foundation Junior Research Fellowships. Peter J Counihan was supported by a Squibb Cardiovascular Research Fellowship. Presented in part at the young research workers competition, British Cardiac Society young research workers competiti
Meeting, Harrogate, May 1992.

1 Wade OL, Bishop JM. Cardiac output and regional blood flow. Oxford: Blackwell, 1962

2 Rowell L. Redistribution of blood flow during exercise. In: Shepherd J, Abboud F, Geiger S, eds. Handbook of physiology (American Physiological Society). The cardiovascular system. The peripheral-circulation, part 2. Baltimore: Waverly Press, 1983:1004-9.

3 Abboud F, Thames M. Interaction of cardiovascular reflexes in circulatory control. In: Shepherd J, Abboud F, Geiger S, eds. Handbook of physiology (American Physiological Society). The cardiovascular system. The Physiological Society). The cardiovascular system. The
peripheral circulation, part 2. Baltimore: Waverley Press, peripheral circula

4 Mancia G, Donald D, Shepherd J. Inhibition of adrenergic outflow to peripheral blood vessels by vagal afferents
from the cardiopulmonary region in the dog. Circ Res from the cardiop

5 Thames $M$, Abboud $F$. Interaction of somatic and cardiopulmonary receptors in control of renal circulation. $\mathrm{Am}$ f Physiol 1979;237:H560-5.

6 Thames M, Miller B, Abboud F. Baroreflex regulation of renal nerve activity during volume expansion. $A m \mathcal{J}$ Physiol 1982;243:H810-4.

7 Hirsch A, Levenson D, Cutler S, Dzau V, Creager M. Regional vascular responses to prolonged lower body negative pressure

8 Bevegard B, Shepherd J. Reaction in man of resistance and capacitance vessels in forearm and hand to leg and capacitance vessels in forearm and

9 Rea R, Eckberg D. Carotid baroreceptor-muscle sympathetic relation in humans. Am $\mathcal{J}$ Physiol 1987;253:R 929-34.

10 Jones $\mathrm{N}$. Evaluation of a microprocessor controlled exercise testing system. F Appl Physiol 1984;57:1312-8.

11 Greenfield A, Whitney R, Mowbray J. Methods for the investigation of peripheral blood flow. British Medical Bulletin 1963;19:101-9.

12 Whitney R. Measurement of volume changes in human limbs. f Physiol 1953;121:1-27.

13 Haywood G, Stewart J, Counihan P, Sneddon J, Tighe D, McKenna W. Validation of bedside measurements of absolute human renal blood flow by a continuous thermodilution technique. Crit Care Med 1992;20:659-64.

14 Counikan' $P$, Frenneaux M, Webb D, McKenna W. Abnormal vascular responses to supine exercise in hypertrophic cardiomyopathy. Circulation 1991;84: 686-96.

15 Bevegard B; Shepherd J. Regulation of the circulation during exercise in man. Physiol Rev 1967;47:178-213.

16 Rowell $\mathrm{L}$. Human cardiovascular adjustments to exercise and thermal stress. Physiol Rev 1974;54:75-159.

17 Blair D, Glover W, Roddie I. Vasomotor responses in the human arm during leg exercise. Circ Res 1961;9:264-74.

18 Walker J, Abboud F, Mark A, Thames $M$. Interaction of cardiopulmonary and somatic reflexes in humans. $\mathcal{F}$ Clin Invest 1980;65:1491-7.

19 Mohanty P, Thames M, Arrowood J, Sowers J, McNamara C, Szentpetery S. Impairment of cardiopulmonary baroreflex after cardiac transplantation in humans. Circulation 1987;75:914-21.

20 Pope S, Stinson E, Daughters G, Schroeder J, Ingels N, Alderman E. Exercise response of the denervated heart in long-term cardiac transplant recipients. Am $¥$ Cardiol in long-term cardia

21 Banner N, Lloyd M, Hamilton R, Innes J, Guz A, Yacoub $M$. Cardiopulmonary response to dynamic exercise after heart and combined heart-lung transplantation. $\mathrm{Br}$ Heart $\mathcal{A}$ 1989;61:215-23.

22 Stevenson L, Sietsema K, Tillisch J, et al. Exercise capacity for survivors of cardiac transplantation or sustained medical therapy for stable heart failure. Circulation 1990;81:78-85.

23 Manohar M. Blood flow to the respiratory and limb muscles and to abdominal organs during maximal exertion in ponies. I Physiol (Lond) 1986;377:25-35.

24 Dicarlo $S$, Bishop V. Regional vascular resistance during exercise: role of cardiac afferents and exercise training. Am $\mathcal{F}$ Physiol 1990;258:H842-7.

25 Higgins C, Vatner S, Frankiin D, Braunwald E. Effects of experimentally produced heart failure on the peripheral experimentally produced heart failure on the peripheral Circ Res 1972;31:186-94.

26 Merrill A, Cargill W. The effect of exercise on the renal plasma flow and filtration rare of normal and cardiac subjects. F Clin Invest 1948;27:272-7.

27 Grimby G. Renal clearances at rest and during prolonged supine exercise at different loads. $\mathcal{F}$ Appl Physiol 1965;20:1294-8

28 Werkö $\mathrm{L}$, Bucht $\dot{H}$, Josephson $B$. The renal extraction of para-aminohippuric acid and oxygen in man during postural changes of the circulation. Scand 7 Clin Lab Invest 1949;1:321-7.

29 Bucht H, Ek, J, Eliasch H, Holmgren A, Josephson B, Werko $L$. The effect of exercise in the recumbent position on the renal circulation and sodium excretion in normal individuals. Acta Physiol Scand 1953:28:95-100.

30 Radigan L, Robinson S. Effects of environmental heat stress and exercise on renal blood flow and filtration stress and exercise on renal blood
rate. $\mathcal{F}$ Appl Physiol 1949;2:185-91.

31 Selkurt E. The renal circulation. In: Hamilton $W$, Dow P, ed. Handbook of physiology (American Physio logical Society). Baltimore: Waverley Press, 1975:1483.

32 Bishop J, Wade $\mathrm{O}$, Donald $\mathrm{K}$. Changes in jugular and renal arteriovenous oxygen content difference during exercise in heart disease. Clin Sci 1958;17:611-9.

33 Scherrer U, Rollins J, Tindall R, Morgan B, Victor R. Does cyclosporine stimulate sympathetic outflow in humans. Circulation 1989;80(suppl 2):11-89.

34 Matsukawa $K$, Mitchell J, Wall P, Wilson L. The effect of static exercise on renal sympathetic nerve activity in conscious cats. F Physiol (Lond) 1991;434:453-67.

35 Pflugfelder P, Purves P, McKenzie F, Kostuk W. Cardiac dynamics during supine exercise in cyclosporine-treated orthopic heart transplant recipients: assessment by radionuclide angiography. $f$ Am Coll Cardiol 1987;10: $336-41$.

36 Wilson R, Christensen B, Olivari M, Simon A, White C, Laxson D. Evidence for structural sympathetic reinnervation after orthotopic cardiac transplantation in vation after orthotopic cardiac tran
humans. Circulation 1991;83:1210-20.

37 McNally $P$, Walls J, Feehally J. The effect of nifedipine on renal function in normotensive cyclosporin-A-treated
renal allograft recipients. Nephrol Dial Transplant 1990;5:962-8. 